\title{
FIRST RECORD OF A WILD POPULATION OF LAELIA DAWSONII F. DAWSONII (ORCHIDACEAE) FOR THE STATE OF JALISCO, MEXICO
}

\author{
Miguel J. Cházaro-Basáñez ${ }^{1}$, Alexander Jiménez-VÁzquez ${ }^{1,3}$ \\ \& Eduardo A. PÉrez-García ${ }^{2}$ \\ ${ }^{1}$ Laboratorio de vida silvestre, Facultad de Biología, Universidad Veracruzana, Lomas del Estadio s/n, \\ Xalapa, Veracruz, 91000, México. \\ ${ }^{2}$ Departamento de Ecología y Recursos Naturales, Facultad de Ciencias, Universidad Nacional \\ Autónoma de México, Ciudad Universitaria, Coyoacán, Ciudad de México, 04510, México. \\ ${ }^{3}$ Author for correspondence: aleko.jimenez22@gmail.com
}

\begin{abstract}
The existence of a wild population of Laelia dawsonii f. dawsonii is recorded for the first time in the Mexican State of Jalisco. Laelia dawsonii has a wide geographical distribution throughout the Sierra Madre del Sur (Oaxaca, Guerrero, and Jalisco); however, the populations are very isolated, and each one has very few individuals. Until now, no wild populations of this species had been registered outside of the State of Oaxaca. The population found in Jalisco is composed of about 100 plants. Due to its horticultural importance, L. dawsonii has been frequently extracted from the field, and its Oaxacan populations have been decimated since the end of the $19^{\text {th }}$ century. Currently, this species is considered endangered in Mexico.

RESUMEN. Se registra por primera vez la existencia de una población silvestre de Laelia dawsonii f. dawsonii en el estado de Jalisco. Laelia dawsonii tiene una amplia distribución geográfica a lo largo de la Sierra Madre del Sur (Oaxaca, Guerrero, y Jalisco); sin embargo, sus poblaciones están muy aisladas y cada una cuenta con muy pocos individuos. Hasta ahora, no se habían registrado poblaciones silvestres de esta especie fuera del estado de Oaxaca. La población encontrada en Jalisco cuenta con alrededor de 100 ejemplares. Debido a su importancia hortícola, $L$. dawsonii ha sido frecuentemente extraída del campo y sus poblaciones oaxaqueñas fueron diezmadas desde finales del siglo XIX. Actualmente, esta especie se considera en peligro de extinción en México.
\end{abstract}

Keywords/PAlabras Clave: biogeografía, biogeography, conservación, conservation, Laeliinae, Laelia anceps

Introduction. Among all the Mexican orchids, Laelia dawsonii (J.Anderson) De B.Crawshay is perhaps one of the most important from the horticultural perspective (Hágsater et al. 2005). However, its taxonomic recognition has been unclear, and many aspects of its life history and its distribution remain unknown (Anderson 1868, Crawshay 1902, Soto-Arenas 2008, Pérez-García 2020). Part of the lack of taxonomic clarity of this species lies in its great horticultural value, particularly because of its similarity to some cultivars of Laelia anceps Lindl. Until recently, $L$. dawsonii was considered a subspecies of $L$. anceps (Soto-Arenas 1993, Pérez-García 2020).

In 1836, John Lindley described Laelia anceps from plants imported to England from Mexico by the London firm Loddiges and Sons. These plants had no exact place of origin (Halbinger \& Soto-Arenas 1997), but most likely, they came from the state of Veracruz.
The flowers of the type had the predominant coloration of that species in the Sierra Madre Oriental, which is lilac with the lip apex in a stronger tone (Fig. 1A).

Laelia anceps has a wide distribution in the Gulf of Mexico slope, from Tamaulipas to the center of Veracruz, and in the states of Guanajuato, Hidalgo, Puebla, Querétaro, San Luis Potosí, and Oaxaca's Sierra Norte (or Sierra de Juárez). In addition, there are small populations of this species on the border between Chiapas and Guatemala, but they usually have a slightly different coloration (Archila et al. 2014). The plants of Guatemala and Honduras have recently been considered a different species, Laelia mottae Archila, Chiron, Szlach. \& Pérez-García. The beauty of $L$. anceps flowers has made it one of the most cultivated Mexican orchids in the world (Rose 1987, Bechtel 1990). Likewise, many horticultural varieties have been found, which have been described as taxonomic 
varieties (Rolfe 1922, Soto-Arenas 1993). This most likely has been one of the problems that has led to the non-recognition of $L$. dawsonii as a correct species, particularly because of the presence of cultivars of $L$. anceps with alba and semialba flowers (Cetzal-Ix et al. 2020, Pérez-García 2020).

Laelia dawsonii.- In 1865, John Tucker sent to Europe several plants classified as L. anceps from the state of Oaxaca, particularly close to the city of Juquila. These specimens were mostly semi-alba flowers, with rhombic petals, thicker lip callus and three to five terminal keels, and with the mid-lobe concave and longer, it was visually a more beautiful shape (SotoArenas 1993, Halbinger \& Soto-Arenas 1997, PérezGarcía 2020). The first plant to bloom was described as L. anceps var. dawsonii by J. Anderson in 1868, and later, some other varieties were described, which to date are considered taxonomic synonyms but that in horticulture still have some use (like the sanderiana variety named by H. G. Reichenbach in 1887). Tucker never revealed the location of the wild populations of this new variety, and by 1892 , Henry Frederick Conrad Sander would relate that all these plants would have been bought from the Oaxacan indigenous people who had cultivated them in towns near the Pacific coast for several centuries (Soto-Arenas 2008).

In 1947, Thomas MacDougall collected specimens in their natural habitat, again without revealing their location, although it is inferred that it was at some point in the Chontal region of Oaxaca (MacDougall 1943, 1948), and although the area was subsequently explored on different occasions, no wild populations have been found in that area (Halbinger \& Soto-Arenas 1997). In 1987, some specimens were found in southern Oaxaca, it was a very small and threatened population, which consisted of only 12 genets (individuals or horticultural clones; Soto-Arenas 2003), but apparently, this locality has already been extirpated. Laelia dawsonii has just been recognized as a distinct species from $L$. anceps and was characterized as an endangered species in the most recent update of the list of threatened species in Mexico (SEMARNAT 2019). Laelia dawsonii presents an important morphological variation and two different forms are recognized: L. dawsonii f. dawsonii and L. dawsonii f. chilapensis (Halbinger \& SotoArenas 1997, Cetzal-Ix et al. 2020).
Laelia dawsonii f. chilapensis (Soto Arenas) PérezGarcía \& Cetzal.- This form of L. dawsonii has a limited geographical distribution since it is only known from some specimens traditionally cultivated in the Chilapa region, Guerrero. These plants have pale pink flowers with velvety dark purple lips (Fig. 1B). To date, wild populations of $L$. dawsonii f. chilapensis have not been documented, which is why it is considered as probably extinct in nature (Soto-Arenas 1993, 2008, Halbinger \& Soto 1997, Pérez-García 2020).

Laelia dawsonii f. dawsonii.- This form generally has white tepals, although some specimens have slightly pinkish tones. The lip is white with the throat with purple lines, the mid-lobe of the lip can vary in extension and be white (Fig. 1C) or magenta in different degrees of color intensity (var. sanderiana, Fig. 1D). It is an orchid in danger of extinction in nature (SotoArenas 2008). Before this publication, it was only known from a few wild populations and cultivated plants in the state of Oaxaca (Huerta Espinoza 2014). Due to its attractive flowers, many specialists and hobbyists have searched intensively for $L$. dawsonii in the wild without finding it. The dawsonii form was considered endemic to Oaxaca since it had only been collected from the wild in that state. However, for some time, the existence of some specimens cultivated by the locals in the state of Jalisco has been known. This prior knowledge motivated Federico Halbinger to go in 1994 to the state of Jalisco in search of these plants. In this botanical expedition, Halbinger was accompanied by Ignacio Contreras, a passionate lover of orchids from Jalisco, but they only found cultivated specimens and none in the wild.

Subsequently, several other collectors interested in the orchids of Jalisco have made expeditions in search of this species without success. For example, Salvador Rosillo de Velasco, from Guadalajara, purchased it in a house in Chiquilistlán, and made countless field trips, collecting orchids in Jalisco and neighboring states, and never found it in the wild. Likewise, Roberto González Tamayo, another prominent orchidologist at the Botanical Institute of the University of Guadalajara, explored the state of Jalisco for more than 40 years and never found it. After the expedition with F. Halbinger, Ignacio Contreras continued for more than 18 years in search of this orchid in its habitat, without being able 

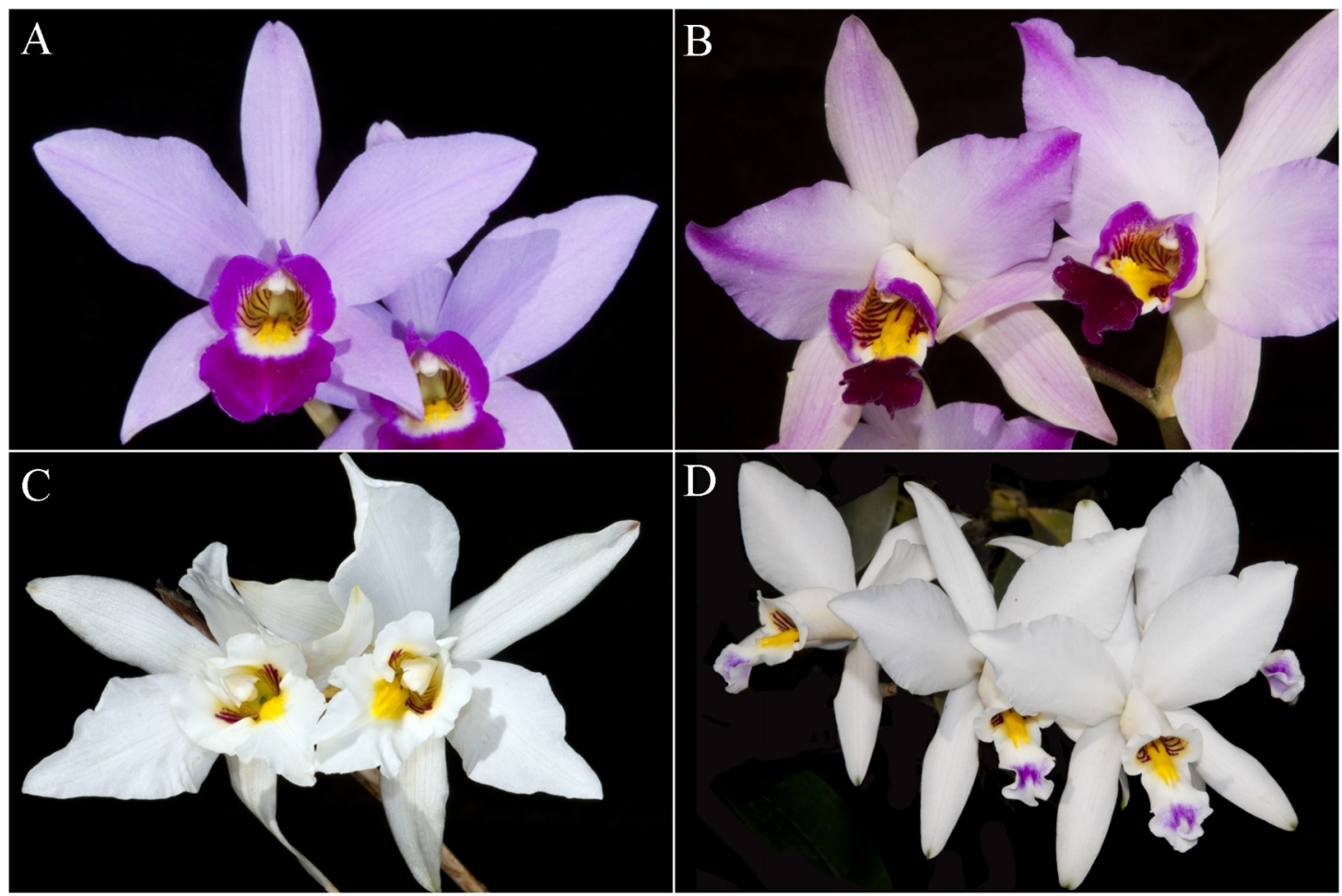

Figure 1. A. Laelia anceps type. B. Laelia dawsonii f. chilapensis. C. Laelia dawsonii f. dawsonii cultivated by locals in Jalisco. D. Laelia dawsonii f. dawsonii "var. sanderiana".

to do so. In 1985, Rogers McVaugh only recorded the following five species of the genus Laelia Lindl. for the Nueva Galicia region (Jalisco and surrounding states): L. albida Bateman ex Lindl., L. autumnalis (Lex.) Lindl., L. crawshayana Rchb.f. (cited as $L$. bancalari), L. rubescens Lindl., and L. speciosa (Kunth) Schltr., in such a way that this great botanical work did not consider the presence in the state of $L$. dawsonii (McVaugh 1985).

Recently, L. Peraza-Flores, G. Carnevali \& C. van den Berg (2016) proposed two groups within the genus Laelia, based in a molecular analysis. The first consists of the endemic species of Mexico, of which $L$. speciosa is the type of the generic name. The second group includes taxa mainly from Central and South America, generally known as Schomburgkia Lindl. Therefore, according to this proposal, the recognition of Laelia would only be for Mexican species close to $L$. speciosa, and the rest of the species including $L$. anceps and $L$. dawsonii to the genus Schomburgkia. For reasons similar to those discussed in Cetzal et al. (2020), in this article, we adopt the broader constituency of Laelia to avoid the increase in binomials associated with the Mexican species of the genus.

Study area.- The discovery site is located in the extensive Sierra del Tigre, southeast of the state of Jalisco. The exact municipality will not be revealed to protect the population of this vulnerable orchid. The site is located at an elevation of $2100 \mathrm{~m}$ above sea level and is made up of lands belonging to the Tertiary period, composed of limestone, extrusive igneous rocks, rhyolite, andesite, basalt, tuff and volcanic breccia. The climate is classified as semi-dry, with dry and semi-warm autumn and winter, with no welldefined winter thermal change. The average annual temperature is $15^{\circ} \mathrm{C}$, and it has an average annual rainfall of $780 \mathrm{~mm}$. This natural area is represented by 8300 ha of forest, where species of Pinus L., Quercus L., and Fraxinus L. predominate, as well as Enterolobium cyclocarpum (Jacq.) Griseb. Currently, the area has a presence of drug trafficking, making botanical exploration risky. 


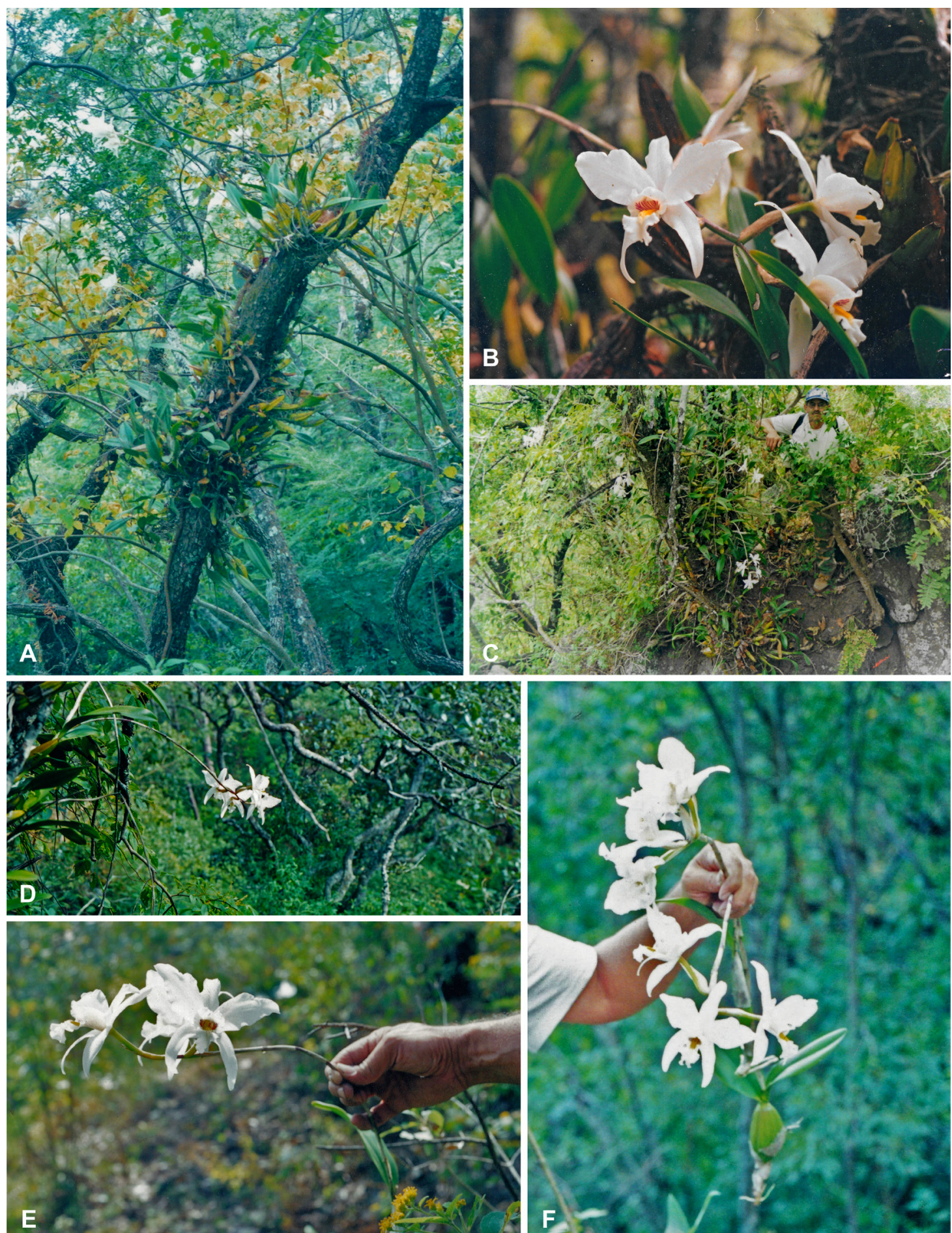

Figure 2. Laelia dawsonii f. dawsonii, in situ, Jalisco, Mexico. A-B. Inflorescences in epiphytic plants. C. Ignacio Contreras with inflorescences in the field. D. Plants growing over rocky cliff. E-F. View of Laelia dawsonii f. dawsonii flowers. 
Results and discussion. In order to photograph specimens of some Crassulaceae species in situ, on April 8, 2001, an expedition was made to the Sierra del Tigre. Thus, when looking for plants in a rocky cliff, it was observed that at the height of $20 \mathrm{~m}$, there was a rupicolous orchid that at first glance looked like an Epidendrum ciliare L. However, when approaching the plant from the upper part of the cliff it was a specimen of the genus Laelia. As the specimen was in a sterile stage, a plant was collected and cultivated in Guadalajara. The plant bloomed in mid-November of that same year. Thus, it was possible to verify the identity of the species as the elusive Laelia dawsonii f. dawsonii, and to locate the first population found in the wild in the state of Jalisco. To photograph with a roll film camera and collect specimens for herbarium, a second visit was made to the Sierra del Tigre on November 20, 2001, where it was possible to observe the population in bloom and reaffirm the identity of the species in nature.

This finding, although fortuitous, is of great importance because it represents the first record with certainty for the state of Jalisco of a wild population of L. dawsonii f. dawsonii (Fig. 2), which is one of the few known populations for this species in Mexico. Interestingly, that the dawsonii form has a population so distant from the known localities for this species in the state of Oaxaca. In other words, Guerrero and Michoacán are skipped.

Due to the large surface area and the rugged topography of the Sierra del Tigre (both in the south of Jalisco and in the northwest of Michoacán) and the limited botanical exploration that has taken place in this geographical region, it is necessary to investigate if L. dawsonii f. dawsonii may be present in other gullies with similar conditions in the region. It is expected that in future botanical expeditions the permanence of the population found can be verified and evaluate if this population is in a position to continue perpetuating itself, that is, with the formation of capsules and the presence of seedlings. It would also be important to perform an accurate count of the number of plants that make up the population and evaluate its dynamics, as well as their reproductive biology. All these aspects of the ecology and natural history of the species remain unknown, even for the populations of Oaxaca. Laelia dawsonii is one of the most spectacular orchids in Mexico, and unfortunately, also one of the most endangered. For this reason, the conservation of the Sierra del Tigre, Jalisco, should be a priority.

Specimens examined-L Laelia dawsonii f. dawsonii MEXICO: Jalisco, Sierra del Tigre, at $1900 \mathrm{~m}$ above sea level, growing epiphytic on Garrya laurifolia Hartw. ex Benth. November 20, 2001, M. Cházaro B., I. Contreras V., R. López V., J. A. Machuca N. \& O. M. Valencia P. \#8153 (ENCB, IBUG, IEB).

Acknowledgments. To Ignacio Contreras Villaseñor, who detected the species during the first expedition in 2001 and for cultivating it until flowering. To J. A. Machuca Núñez, Óscar M. Valencia Pelayo, J. Cortés Aguilar and Raúl López Velázquez, who actively collaborated in the field work. To Fernando Rico Román for having transcripted the first manuscript on the computer, and Eduardo Sahagún Godínez who made important comments on the first versions of this manuscript. We are grateful to Tania del Rocío Ruiz Estrada for the composition of the figures. To Raúl López Velázquez for the pictures 2B and 2C. To PAPIIT-DGAPAUNAM grant IN227319 for supporting the maintenance and photographic documentation of the orchid collection at MAS-FC-UNAM Orchidarium. M.J. C-B. appreciates the valuable financial support received during many years of academic work and botanical research in the Department of Geography and Territorial Planning of the University of Guadalajara, to be able to carry out field work in Jalisco.

\section{LiTERATURE CITED}

Anderson, J. (1868). New plants. The Gardeners' Chronicle \& Agricultural Gazette, 2, 27.

Archila, F., Chiron, G., Szlachetko, D., Bertolini, V. \& Pérez-García, E. A. (2014). Laelia mottae (Orchidaceae): una nueva especie del complejo de Laelia anceps Lindl. Botanical Sciences, 92, 343-350.

Bechtel, P. G. (1990). The Laelias of Mexico. American Orchid Society Bulletin, 59(12), 1229-1234.

Cetzal-Ix, W., Carnevali, G., Jiménez-Machorro, R. \& Pérez-García, E. A. (2020). Laelia $\times$ meavei: A new natural hybrid between L. dawsonii f. dawsonii and L. rubescens f. peduncularis (Orchidaceae: Laeliinae) from Oaxaca, Mexico. Phytotaxa, 446 (2), 81-94.

Crawshay, B. (1902). Laelia anceps and its varieties. The Gardeners' Chronicle: A Weekly Illustrated Journal of Horticulture 
and Allied Subjects, ser. 3, 32, 414.

Hágsater, E., Soto-Arenas, M. A., Salazar-Chávez, G. A., Jiménez, R., López-Rosas, M. A. \& Dressler, R. L. (2005). Las Orquídeas de México. Mexico City: Instituto Chinoin. 304 pp.

Halbinger, F. \& Soto-Arenas, M. (1997). Laelias of Mexico. Orquídea (Mexico City), 15, 1-160.

Huerta Espinoza, H. M. (2014). Evaluación del efecto del cambio de uso del suelo en la distribución de las especies mexicanas de Laelia (Orchidaceae). Licenciatura en Geografía, Facultad de Filosofía y Letras, Universidad Nacional Autónoma de México. 138 pp.

Lindley, J. (1836). Laelia anceps: two-edged Laelia. Edwards's Botanical Register, 21, t. 1751.

MacDougall, T. (1943). White varieties of Laelia anceps. American Orchid Society Bulletin, 11(11), 395-396.

MacDougall, T. (1948). White Laelia anceps in Mexico: a photo-story. American Orchid Society Bulletin, $17(10), 606-607$.

McVaugh, R. (1985). Orchidaceae. In: W. R. Anderson (ed.), Flora Novo-Galiciana. 16. Ann Arbor, Michigan: University of Michigan Press. 363 pp.

Peraza-Flores, L. N., Carnevali, G. \& van den Berg, C. (2016). A molecular phylogeny of the Laelia alliance (Orchidaceae) and a reassessment of Laelia and Schomburgkia. Taxon, 65(6), 1249-1262.

Pérez-García, E. A. (2020). Die "Sanderiana”, eine Geschichte über Laelia dawsonii. Die Orchidee, 71(4), $276-285$.

Reichenbach, H. G. (1887). Plants new or noteworthy: Laelia anceps var. sanderiana. The Gardeners'chronicle: a weekly illustrated journal of horticulture and allied subjects, series 3, vol. 1, 104.

Rolfe, R. A. (1922). Laelia anceps and its varieties. Orchid Review, 30, 7-11.

Rose, J. (1987). Laelia anceps - The real treasure of the Sierra Madre. American Orchid Society Bulletin, 56(5), 483-491.

Secretaría de Medio Ambiente y Recursos Naturales (SEMARNAT). (14 de noviembre de 2019). Modificación del Anexo

Normativo III, Lista de especies en riesgo de la Norma Oficial Mexicana NOM-059-SEMARNAT-2010, Protección ambiental-Especies nativas de México de flora y fauna silvestres-Categorías de riesgo y especificaciones para su inclusión, exclusión o cambio-Lista de especies en riesgo, publicada el 30 de diciembre de 2010. Diario Oficial de la Federación. Recuperado de http://www.dof.gob.mx/nota_to_imagen_fs.php?codnota=5578808\&fecha=14/11/2019\&c od_diario $=283778$

Soto-Arenas, M. A. (1993). Clasificación infraespecífica de Laelia anceps. Orquídea (Mexico City), 13, $125-144$.

Soto-Arenas, M. A. (2003). Laelia anceps Lindl. subsp. dawsonii (J.Anderson) Rolfe f. dawsonii. In: E. Hágsater \& M. A. Soto-Arenas (Eds.), Icones Orchidacearum fascicles 5 and 6, Orchids of Mexico parts 2 and 3, pl. 597. México, D.F: Herbario AMO.

Soto-Arenas, M. A. (2008). Laelia anceps subsp. dawsonii f. chilapensis Soto-Arenas. In: E. Hágsater \& M. A. Soto-Arenas (Eds), Icones Orchidacearum 10, pl. 1035. México, D.F.: Herbario AMO. 